\title{
Assessment of the Levels of Serum Iron and Magnesium in Sudanese Cigarette Smokers
}

\author{
Sulafa Ali Abdalla Mudawi ${ }^{1}$, Samia Mahdi Ahmed ${ }^{2}$, Dr Badr Aldeen Hassan \\ $\mathrm{Al}-\mathrm{Abd}^{3}$ \\ ${ }^{1}$ M.sc in Clinical chemistry, College of Medical Laboratory Sciences, Sudan University of Science \& \\ Technology, Khartoum, Sudan \\ ${ }^{2}$ Assistant professor, Department of Medical Laboratories, College of Applied Medical Sciences, \\ Taibah University, Almadeena Almonawara, Saudi Arabia \\ ${ }^{3}$ Associate professor, MD in Clinical Pathology, Ph.D in Clinical chemistry, College of Medical \\ Laboratory Sciences, University of Science \& Technology, Khartoum, Sudan
}

\begin{abstract}
Smoking is one of the biggest public health throughout the world. This cross-sectional study was carried out to determine the effect of cigarette smoking on serum iron and magnesium level; 70 smokers males (aged 18-35 years old), and 30 non smokers males (aged 18-35 years old, as control) were enrolled. Three ml of fasting venous blood were collected from each volunteer, serum obtained and analyzed lorimetrically. Statistical analysis revealed that serum iron was significantly higher in smokers compared to non smokers. Serum iron did not change due to age difference. There was insignificant difference between the mean of serum iron in smokers who smoked $\leq 15$ cigarettes per day compared to those who smoked $\geq 15$ cigarettes per day. No correlation found between iron level and the number of cigarettes per day, also no correlation found between iron level and duration of smoking.Serum magnesium was significantly lower in smokers compared to non smokers. Magnesium level did not change due to age difference. Serum magnesium was significantly decreased in those who smoke more than 15 cigarettes per day. A weak negative correlation found between serum magnesium and the number of cigarettes per day, also a weak negative correlation found between serum magnesium and the duration of smoking.
\end{abstract}

KEYWORDS: Cigarette smoking, serum iron, serum magnesium

\section{INTRODUCTION}

Smoking is a practice in which a substance, most commonly tobacco or cannabis is burned and the smoke tasted or inhaled. The most common method of smoking today is through cigarettes [1]. Tobacco use leads most commonly to diseases affecting the heart and lungs, with smoking being a major risk factor for heart attacks, strokes, chronic obstructive pulmonary disease (COPD), emphysema, and cancer. It also causes peripheral vascular disease and hypertension, all developed due to the exposure time and the level of dosage of tobacco [2].Minerals are very essential substances involved as catalysts in most cellular enzymatic reactions and assume a major role in metabolism [3].

Iron and magnesium are examples of these essential minerals. Functions of iron include involvement in energy metabolism, gene regulation, cell growth and differentiation, oxygen binding and transport, muscle oxygen use and storage [4]; [5],...etc. Magnesium is a critical cation and cofactor in numerous intracellular processes. it is involved in more than 300 essential metabolic reactions, some of which are: energy production, synthesis of essential molecules, structural roles, ion transport across cell membranes, cell signaling, and cell migration [6]. Literature survey showed that no sufficient work has been done to study the effect of cigarette smoking on serum minerals alterations, so this study was carried out to determine the influence of cigarette smoking on serum iron and magnesium levels among Sudanese smokers and to determine the relationship between the levels of serum iron and magnesium with age, number of cigarettes per day, and duration of smoking.

Cigarette smoking causes minerals disturbances which lead to serious consequences, Smoking leads to tissue hypoxia which leads to inadequate oxygenation of blood circulation that results in erythropoiesis and consequent increased production of erythropoietin [7] which enhances erythropoiesis and increases red cell mass above normal level [8]. This leads to increase in the number of destroyed red cells in the normal turnover process which subsequently increases iron overload which causes hepatocellular damage [9]. Chronic oxidative 
stress may modulate iron uptake and storage, leading to a self sustained and ever-increasing spiral of cytotoxic and mutagenic events [10].

Smoking causes magnesium deficiency due to decreased supply (lesser appetite) and reduced absorption caused by disturbances in the digestive system functions [11]. Minerals disturbances may lead to sever and even lifethreatening metabolic abnormalities such as coronary heart disease, liver disease, lung infection, kidney failure, and disorders of endocrine system [12].

\section{MATERIALS AND METHODS}

Hundred male Volunteers were enrolled in this study. During the period of 5-30 April 2011; of those seventy volunteers were cigarette smokers (aged 18-35 years old), and thirty were non smokers (aged 18-35 years old, as control group).They were residing in Khartoum state. Both groups were without history of alcohol consumption, chronic diseases, recent blood transfusion and drugs that affect analysis results. Volunteers were enrolled in the study after being fully informed about the aims of the study. In addition, written consents had been obtained. And the results of analysis (iron and magnesium levels) were offered free of charge for all of them.

\subsection{Methods}

2.1.1Subject's history

The history included information about the volunteers obtained from them according to the designed study questionnaire.

\subsubsection{Samples collection}

Under a septic condition, about $3 \mathrm{ml}$ of venous blood were collected from each volunteer by venipuncture technique (after overnight fasting 10-12 hours, and in the morning to avoid diurnal variation of iron.) and were placed in anticoagulant free containers, and allowed to clot then centrifuged at 3000 rpm for 5 minutes to obtain serum which kept in eppendorf tubes for measurements of iron and magnesium.

\subsubsection{Measurement of serum iron}

Serum iron was measured photometrically using Jenway colorimeter by CAB method (chromazurol B). Iron react with chromazurol $\mathrm{B}$ and cetyltrimethylammonium bromide (CTMA) to form a colored ternary complex with an absorbance maximum at $623 \mathrm{~nm}$. The intensity of the color produced was directly proportional to the concentration of iron in the sample. The procedure of this method included addition of 50 $\mu 1$ of sample (non hemolysed serum) and standard to $1 \mathrm{ml}$ of reagent pipetted into two separate test tubes, with incubation time of 15 minutes, also $1 \mathrm{ml}$ of the reagent with $50 \mu \mathrm{l}$ deionized water were pipetted into a third tube as blank. Then the absorbance of the sample and standard was measured at $623 \mathrm{~nm}$ against the reagent blank within 60 minutes. Serum iron concentration was calculated according to formula:

$$
\mathrm{C}(\mu \mathrm{g} / \mathrm{dl})=\mathrm{C}(\mathrm{STD}) \times \Delta \mathrm{A}_{\text {sample }} \div \Delta \mathrm{A}_{\text {STD }}
$$

\subsubsection{Measurement of serum magnesium}

Serum magnesium was measured photometrically using Jenway Colorimeter by Xylidyl blue method. Magnesium ions in an alkaline medium formed a colored complex with Xylidyl blue. The absorbance increase was proportional to the magnesium concentration in the sample. Glycoletherdiamine-N, N, N, N-tetra acetic acid (GEDTA) was used as masking agent for calcium ions. The procedure included the addition of $10 \mu \mathrm{l}$ of sample (non hemolysed serum) and standard to $1 \mathrm{ml}$ reagent into two test tubes, with incubation time 10 minutes, also $1 \mathrm{ml}$ of the reagent with $10 \mu \mathrm{l}$ deionized water were pipetted into a third tube as blank. Then the absorbance of the sample and standard was measured at $520 \mathrm{~nm}$ against reagent blank within 60 minutes.

Serum magnesium concentration was calculated according to formula:

$\mathrm{C}(\mathrm{mg} / \mathrm{dl})=\mathrm{C}(\mathrm{STD}) \times \Delta \mathrm{A}_{\text {sample }} \div \Delta \mathrm{A}$

The obtained results were analyzed statistically using SPSS software program.

\subsection{Age and residence}

\section{RESULTS}

In the present study a total of hundred male volunteers were enrolled; seventy were smokers (70\%), age ranging between 18 and 35 years (mean: 25 years), and thirty were non-smokers (30\%), age ranging between 
18-35 years (mean: 25 years).Of those volunteers 34 were from Khartoum, 47 were from Omdurman, and 19 were from Khartoum-north.

\subsection{Age grouping and percentage}

Age range 18-22 years represented $43 \%$ of all volunteers, followed by age range 23-27 years represented $24 \%$, then those with age more than 32 years represented $19 \%$, and the lowest percentage $14 \%$ of age range 28-32 years. (Table 1)

Table (1): Age group and Percentage

\begin{tabular}{|c|c|c|}
\hline $\begin{array}{c}\text { Age } \\
\text { group }\end{array}$ & Frequency & Percentage \\
\hline $18-22$ & 43 & 43 \\
$23-27$ & 24 & 24 \\
$28-32$ & 14 & 14 \\
$>32$ & 19 & 19 \\
\hline Total & 100 & 100 \\
\hline
\end{tabular}

\subsection{Serum iron}

The analysis results showed that, there was a significant difference in the mean of serum iron between smokers and non-smokers $(140 \pm 52) \mu \mathrm{g} / \mathrm{dl}$ versus $(90 \pm 22) \mu \mathrm{g} / \mathrm{dl}, \mathrm{p}$ value $\quad 0.000,<0.05$ (Figure 1$)$.

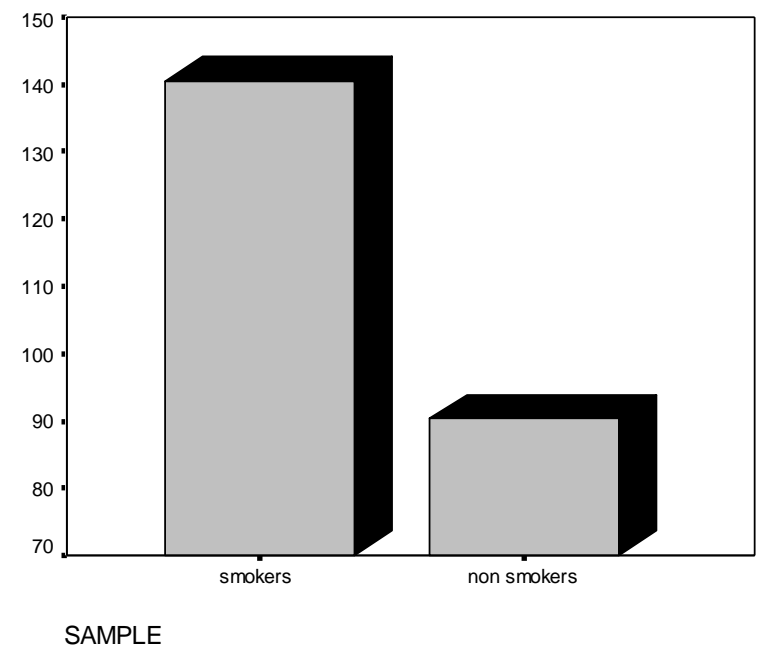

Figure (1): Mean of serum iron in smokers and non smokers

There was insignificant difference in serum iron in the different age groups, $\mathrm{p}$ value $0.2,>0.05$. There was insignificant difference between the mean of serum iron in smokers who smoked $\leq 15$ cigarettes per day $(138 \pm 50) \mu \mathrm{g} / \mathrm{dl}$ compared to those who smoked $\geq 15$ cigarettes per day $(145 \pm 55) \mu \mathrm{g} / \mathrm{dl}$, $\mathrm{p}$ value 0.6 . Also there was no correlation between serum iron and number of cigarettes per day.There was insignificant difference in serum iron with different smoking durations; $p$ value 0.7 , also there was no correlation between serum iron and the duration of smoking.

\subsection{Serum magnesium}

The analysis results showed that, there was a significant difference in the mean of serum magnesium between smokers and non-smokers $(1.4 \pm 0.40) \mathrm{mg} / \mathrm{dl}$ versus $(2.2 \pm 0.39) \mathrm{mg} / \mathrm{dl}, \mathrm{p}$ value $0.000,<0.05$. (Figure 2 ). 


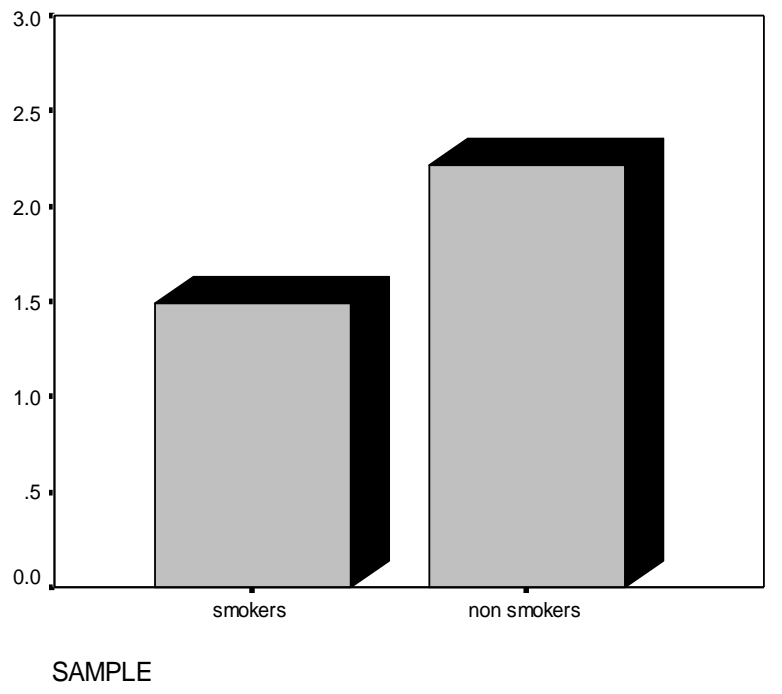

Figure (2): Mean of serum magnesium in smokers and non smokers

There was insignificant difference in serum magnesium in different age groups, $\mathrm{p}$ value 0.4 , $>0.05$. There was significant difference between the mean of serum magnesium in smokers who smoked $\leq 15$ cigarettes per day $(1.5 \pm 0.36) \mathrm{mg} / \mathrm{dl}$ compared to those who smoked $\geq 15$ cigarettes per day $(1.3 \pm 0.35) \mathrm{mg} / \mathrm{dl}, \mathrm{p}$ value 0.03 . (Table 2 ), and there was a weak negative correlation between serum magnesium and the number of cigarettes per day, correlation coefficient $r=-0.2$. There was a weak negative correlation between serum magnesium and the smoking duration, correlation coefficient $r=-0.3$.

Table (2): Mean of serum magnesium in smokers and non smokers

\begin{tabular}{|c|c|c|c|c|}
\hline $\begin{array}{c}\text { number of } \\
\text { cigarettes/day }\end{array}$ & $\begin{array}{c}\text { smokers } \\
\text { number }\end{array}$ & $\begin{array}{c}\text { mean of } \\
\text { serum } \\
\text { magnesium }\end{array}$ & $\begin{array}{c}\text { Std. } \\
\text { Deviation }\end{array}$ & $\begin{array}{c}\mathrm{P} \\
\text { Value }\end{array}$ \\
\hline$<15$ & 53 & 1.5 & 0.36 & \\
$>15$ & 17 & 1.3 & 0.35 & 0.03 \\
\hline
\end{tabular}

\section{DISCUSSION}

Cigarette smoking is a world wide major cause of preventable morbidity and mortality [13] Magnesium is a very essential mineral that serves as a cofactor of many enzymes involved in energy metabolism, protein synthesis, RNA and DNA synthesis, and maintenance of the electrical potential of nervous tissues and cell membranes. Of particular importance with respect to the pathological effects of magnesium depletion is the role of this element in regulating potassium fluxes and its involvement in the metabolism of calcium [14]Also iron is a key element in the metabolism; it is an essential component of hundreds of proteins and enzymes [15]. It is a mineral, functions primarily as a carrier of oxygen in the body, it also aids in immune function, cognitive development, temperature regulation, energy metabolism, and work performance [16].This study involved male volunteers rather than female because it is so difficult to find smoker females as smoking is a shameful for them in our society, although it appears to increase in recent days. Also the study participants were youth as the smoking become more spread among this age group.In the present study a total of hundred volunteers were enrolled; seventy were smokers; age ranging between 18 and 35 years. And thirty were non-smokers; age ranging between 18 and 35 years. This study showed that serum iron was significantly increased in smokers when compared to non smokers ( $p$ value 0.000), this result is in agreement with previous studies [7], [17]; as cigarette smoking induces hypoxia which stimulates erythropoetien production which induces hyperplasia of the bone marrow, the latter contributes to the development of secondary polycythemia and in turn to increased red cell mass and turnover, this increased erythropoiesis and increased red cells mass increases the number of 
destroyed red cells in normal turnover process leading to increased iron overload this finally causes deposition of excessive iron in parynchemal cells of the liver which causes hepatocellular damage [18] Also iron overload may leads to myocardial damage, diabetes, and joints problems [19]. The study revealed that serum magnesium was significantly decreased in smokers when compared to non smokers ( $\mathrm{p}$ value 0.000 ). This result is in agreement with a previous study [20]; as cigarette smoking causes decreased supply of magnesium caused due to lesser appetite and reduced absorption due to digestive system disturbances [11]; depleted magnesium leads to hypertension [21] and cardiovascular diseases [22].

\section{CONCLUSION}

1- Level of serum iron is increased in cigarette smokers, whereas it is not affected by age differences, number of cigarettes, and duration of smoking.2- Level of serum magnesium is decreased in cigarette smokers, it is affected by the number of cigarettes and the duration of smoking, but not affected by the difference in age.3- Serum magnesium should be monitored in smokers in addition magnesium supplementation should be given when necessary.4- Educational programs is necessary to increase people awareness about serious health effects of smoking and the importance of minerals to the body.

\section{REFERENCES}

[1] Shiffman S, Robert S (2007) Fast Facts: Smoking Cessation. Oxford: Health Press Ltd.

[2] Nichter ME, Cartwright (1991) Saving the children for the tobacco industry. Med Anthropol Q 5: 236-256.

[3] John AK (2007) Disorders of acid-base balance. Crit.Care Med 35: 2630-2636.

[4] Provan D (1999) Mechanisms and Management of iron deficiency anaemia. Br J Haematol 105: 19-26.

[5] Beard JL (2001) Iron biology in immune function, muscle metabolism and neuronalfunctioning. J Nutr 131: 568S$579 \mathrm{~S}$

[6] Rude RK, Shils ME.Magnesium. In: Shils ME, Shike M, Ross AC, Caballero B, Cousins RJ, eds. Modern Nutrition in Health and Disease.10th ed. Baltimore: Lippincott Williams\&Wilkins; 2006:223-247.

[7] El -Zayadi AR (2006) Heavy smoking and liver. World J Gastroenterol 12: 6098-6101. [8] Balcerzek SP, Bromberg PA (1975) Secondary polycythemia. Semin.Hematol 12: 339-351.

[9] Bacon BR, Britton RS (1990) The pathology of hepatic iron overload: A free radical-mediated process? Hepatology 11: 127-137.

[10] Emrit J, Beaumont C, Trivin F (2001) Iron metabolism, free radicals, and oxidative injury. Biomed. Pharmacother 55: 333-539.

[11] Winiarczyk AU, Bagniuk A, Lalkowska KG, Szubartowska E (2008) Calcium, Magnesium, Iron, Zinc and Copper Concentration In the Hair of Tobacco Smokers. Biol Trace Elem Res 128: 152-160.

[12] John AK. Disorders of acid base balance. Crit. Care Med.2007; 35:2630-2636.

[13] Funck-Brentanoa C, Mathilde R, Michel L, Amould JP, Verstufyft c, Ronan R (2006) Effects of type of smoking (pipe, cigars or cigarettes) on biological indices of tobacco exposure and toxicity. Lung cancer 54: 1118.

[14] Al-Ghamdi SM, Cameron EC, Sutton RA (1994) Magnesium deficiency: pathophysiologic and clinical overview. Am J Kidney Dis 24: 737-754.

[15] Wood RJ, Ronnenberg AG (2006) Iron. In: Shils ME, Shike M, Ross AC, Caballero $\quad$ B, Cousins RJ, eds. Modern Nutrition in Health and Disease. Philadelphia: Lippincott Williams \& Wilkins.

[16] Fairbanks VF (1999) Iron in Medicine and Nutrition. In: Shils ME, Olson JA, Shike $\quad$ M, Ross AC, eds. Modern Nutrition in Health and Disease. Philadelphia: Lippincott Williams \& Wilkins.

[17] Padmavathi P, Reddy VD, Varadacharyulu N (2009) Influence Of Chronic Cigarette Smoking On Serum Biochemical Profile In Male Human Volunteers. JHS 55: 265-270. [18] Gutteridge JM, Halliwell B (1989) Iron toxicity and oxygen radicals. Baillieres Clin Haematol 2: 195-256.

[19] Janssen MC, Swinkels DW (2009) Hereditary haemochromatosis. Best Pract Res Clin Gastroenterol 23: 171-183.

[20] Peacock JM (2010) Serum magnesium and risk of sudden cardiac death in the Atherosclerosis Risk in Communities (ARIC) Study. Am Heart Journal 160: 464-70.

[21] Peacock JM, Folsom AR, Arnett DK, Eckfeldt JH, Szklo M (1999) Relationship of serum and dietary magnesium to incident hypertension: the Atherosclerosis Risk in Communities (ARIC) Study. Ann Epidemiol 9: 159-165.

[22] Liao F, Folsom AR, Brancati FL (1998) Is low magnesium concentration a risk factor for coronary heart disease? The Atherosclerosis Risk in Communities (ARIC) Study. Am Heart J 136: 480-490. 